\title{
Effect of Tetragonula laeviceps propolis from Thailand on periodontal ligament fibroblast
}

\author{
Mahwash Maalik Baloch ${ }^{1}$, Dutmanee Seriwatanachai ${ }^{1}$, Chanpen Chanchoa ${ }^{2}$, \\ Prakan Thanasrisuebwong 3 , Sujiwan Suebbuk ${ }^{4}$, Rudee Surarit ${ }^{*}$ \\ 1 Department of Oral Biology, Faculty of Dentistry, Mahidol University, Bangkok, Thailand \\ 2 Department of Biology, Faculty of Science, Chulalongkorn University, Bangkok, Thailand \\ 3 Dental Implant Center, Dental Hospital, Faculty of Dentistry, Mahidol University, Bangkok, Thailand \\ Department of Oral medicine and Periodontology, Faculty of Dentistry, Mahidol University, Bangkok, Thailand
}

\begin{abstract}
The aim of this study is to investigate the effect of propolis from Thai Tetragonula laeviceps (Thai stingless bee) on human periodontal ligament fibroblasts (PDLF). Periodontal ligament fibroblasts obtained from Science Cell ${ }^{\mathrm{TM}}$ were cultured in Dulbecco's Modified Eagles Medium (DMEM) containing 10\% fetal bovine serum. The cytotoxicity of propolis was assayed using 3-(4,5-dimethylthiazol-2-yl)-2,5-diphenyltetrazolium bromide (MTT) method. The cell proliferation assay was evaluated in the presence and absence of propolis at different concentrations at day $1,4,7$, and 10 . The horizontal migration assay was performed using scratched assay in monolayer culture, and vertical migration assay was done in a Boyden chamber, stained with toluidine blue $\mathrm{O}$ then counted. The antioxidant activity of propolis was measured based on the scavenging effect on 2,2diphenyl-1-picryl-hydrazyl radical (DPPH). The effect of propolis on bone regeneration was determined using alkaline phosphatase activity and mineralized nodule formation assay. The results showed that propolis, up to $200 \mathrm{mg} / \mathrm{ml}$, respectively, produced no toxicity to PDLF. It was also found that at low concentration propolis could promote PDLF proliferation and cell migration. The antioxidant activity of propolis was dose dependent. It was found that the higher the concentration the higher antioxidant effect. Alkaline phosphatase activity was found to increase markedly at day 14 then decrease in all groups. It was found that propolis could induce nodule formation. In conclusion, propolis from T. laeviceps can promote PDLF cell proliferation, migration and differentiation.
\end{abstract}

\section{Keywords:}

Tetragonula laeviceps, Propolis, Osteoinduction, Periodontal ligament fibroblast

\section{INTRODUCTION}

Periodontal diseases are highly prevalent and can affect up to $90 \%$ of the world population. They have attracted more interest in recent year, since it is becoming evident that such infection can influence systemic health in many ways e.g. heart disease ${ }^{1}$ (Beck et al., 2005), stroke ${ }^{2}$ (Hozomi et al., 2012) and pneumonia in the elderly ${ }^{3}$ (Sharma et al., 2011). It is a chronic infection caused by bacterial infection of the periodontium, resulting in degeneration of tissue. This disease is characterized by an inflammatory reaction in gingival tissue and subsequently destroys periodontal structures including cementum, periodontal ligament and alveolar bone.

An important aspect of periodontal therapies is to slow down or to arrest the progression of the disease by scaling and root planning of the tooth. Medications for example tetracycline, macrolides, quinolone, metronidazole in combination with tetracycline may also be used, and sometimes surgery may be needed. Therapeutic methods may involve tissue engineering to regenerate the alveolar bone, cementum, periodontal ligament and finally prevent recurrence of the disease. Periodontal ligament cells play an important role in regeneration of the periodontium and of the bone, since they possess

*Corresponding author:

*Rudee Surarit rudee.sur@mahidol.ac.th 
stem cell activities.

Propolis is the generic name for a complex mixture of resinous substances that bees collect from plants, and is used to coat the inner walls of the bee hive, to protect the entrance against intruder, and to inhibit the growth of fungi and bacteria. Propolis has been used in dentistry for various purposes and has a promising role for medicine in the future ${ }^{4}$ (Taheri et al., 2011). However, different types of bees produce different propolis due to both species and environment in which they live. Tetragonula laeviceps, stingless bee commonly found in tropical regions, can be commercially cultivated in an artificial beehive and widely distributed throughout Thailand. It was reported to possess antibacterial and antifungal properties ${ }^{5}$ (Umthong et al., 2011) Moreover, it also possessed anti proliferative effect on cancer cell lines ${ }^{6}$. Therefore, the aim of this study is to investigate the effect of T. laeviceps propolis on fibroblasts in human periodontal ligament in terms of cytotoxicity, cell proliferation, cell migration and differentiation.

\section{MATERIALS AND METHODS}

\subsection{Propolis}

T. Laeviceps propolis was kindly provided by Professor Chanpen Chanchao, Department of Biology, Faculty of Science, Chulalongkorn University, Bangkok, Thailand. Propolis from T. laeviceps was collected from hives in a mangosteen (Garcinia mangostana) and rambutan (Nephelium lappaceum) orchard in Makham district, Chantaburi province, Thailand in May 2012. It was wrapped in an aluminum foil and kept in the dark at $-20^{\circ} \mathrm{C}$ until used. Crude extract of propolis was obtained by dissolving $10 \mathrm{~g}$ of propolis in $10 \mathrm{ml}$. of dimethylsulfoxide (DMSO) overnight at room temperature, then centrifuging and keeping the clear supernatant at $4^{\circ} \mathrm{C}$, This will be stock solution at the concentration of $1000 \mathrm{mg} / \mathrm{ml}$ and further diluting with cell culture media to obtain various concentrations of propolis for use in further studies.

\subsection{Cell culture}

Human periodontal ligament fibroblasts (PDLF) were purchased from Science Cell ${ }^{\mathrm{TM}}$ Research Laboratories. Cells were cultured in Dulbecco's Modified Eagle Medium (DMEM), Gibco ${ }^{\mathrm{TM}}$, Invitrogen Corporation with $10 \%(\mathrm{v} / \mathrm{v})$ fetal bovine serum (FBS), Hyclone ${ }^{\circledR}$, Hyclone UK Ltd., UK (complete medium) at $37^{\circ} \mathrm{C}$ in a humidified air atmosphere containing $5 \%(\mathrm{v} / \mathrm{v}) \mathrm{CO}_{2}$.

\subsection{MTT assay for cytotoxicity}

PDLF were added to each well of 96-well plates
(Costar ${ }^{\circledR}$, Corning, USA) at a concentration of $2 \times 10^{4}$ cells in $200 \mu 1$ of DMEM per well. Cells were incubated at $37^{\circ} \mathrm{C}$ in humidified atmosphere of $95 \%$ air and $5 \%$ $\mathrm{CO}_{2}$ for 24 hours. Then cells were treated with various concentrations of propolis for 24 hours. In the negative control group, the cells were treated with DMEM alone. The DMSO concentration was kept less than $1 \%$ which showed no toxicity to cells. Cell viability was assessed by the 3-(4,5-dimethylthiazol-2-yl)-2,5-diphenyltetrazolium bromide (MTT; Sigma-Aldrich, USA) method ${ }^{7}$. (Mosmann, 1983). In brief, cells were washed with 1X PBS and incubated with $0.5 \mathrm{mg} / \mathrm{ml}$ MTT (SigmaAldrich $^{\mathrm{TM}}$, Inc., USA) for 2 hours. After that, they were rinsed again with $1 \mathrm{X}$ PBS. The formazan product was dissolved in DMSO for 30 minutes. The absorbance was measured at $540 \mathrm{~nm}$ using EpochTM microplate spectrophotometer $\left(\right.$ Biotek $^{\circledR}$, USA).

\subsection{Cell proliferation Assay}

PDLF were seeded in 24-well plates (Costar®, Corning, USA) at a density of $2 \times 10^{4}$ cells/well in humidified atmosphere at $5 \% \mathrm{CO}_{2}$ at $37^{\circ} \mathrm{C}$. Cells were treated with propolis at concentrations of 200, 100, 10, $1,0.1 \mu \mathrm{g} / \mathrm{ml}$. The medium was changed every other day and the concentration of propolis was kept at specified concentration. Cell viability was assessed by the 3-(4,5dimethylthiazol-2-yl)-2,5-diphenyltetrazolium bromide (MTT) method $^{8}$ (Jaiswal et al., 1997) at day 1, 4, 7 and 10. In the negative control group, cells were treated with DMEM alone. In the positive control group, cells were treated with $10 \%$ DMSO. All experiments were performed in triplicate.

\subsection{In vitro wound healing assay}

Horizontal migration assay was performed using a modification of the scratch assay method ${ }^{9}$ (Liang et al., 2007). Briefly, a confluent monolayer of PDLF cells were cultured on 24 well plates by seeding cells at the concentration of $1 \times 10^{5}$ cells per $\mathrm{ml}$ of DMEM per well. Cells were incubated for 24 hours at $37^{\circ} \mathrm{C}$ in humidified atmosphere of $95 \%$ air and $5 \% \mathrm{CO}_{2}$. After this incubation period, a wound was created in the cultured cells by scraping cells across the surface of the tissue culture well centrally extending to the edge of the well. The wounded well was rinsed with PBS, and then treated with propolis at various concentrations. Cells were further incubated for 18 hours allowing the remaining cells to migrate into the created wound space. The migrated cells were fixed with iced cold methanol, washed once with deionized water and stained with toluidine blue. Images of cell migration were acquired, and cell migration was determined by counting number of cells migrating into the wounded area. The experiment was performed at least 3 times. 
Vertical migration assay was performed using a Boyden chamber according to Chen, $2009^{10}$. Briefly, PDLF were cultured in a 24 well plates Boyden chamber by seeding $1 \times 10^{5}$ cells in $2 \mathrm{ml}$ of DMEM per well. Cells were incubated at $37^{\circ} \mathrm{C}$ in humidified atmosphere of $95 \%$ air and $5 \% \mathrm{CO}_{2}$. After 24 hours, cells were treated with propolis at various concentrations and then cells were further incubated for another 24 hours allowing the cells to migrate vertically. The migrated cells were fixed with ice-cold methanol for 2 minutes and washed with deionized water once then stained with toluidine blue for 2 minutes followed by washing with deionized water twice. Cell migration images were acquired. Six areas were taken for each well. Cell migration was determined by counting the number of cells which moved to the bottom side of the filter. The experiment was performed at least 3 times.

\subsection{Mineralized nodule formation and quantification}

Three experiments were performed according to the method by Nohutcu et al., $1997^{11}$. Cells were observed daily and media was collected at days 7, 14, 21 and 28. PDLF cells were seeded at the concentration of $2 \times 10^{3}$ cells per well in a 12 well plates for 24 hours and then treated with crude propolis at the concentration of $0.1 \mu \mathrm{g} / \mathrm{ml}$. Bone inducers $(50 \mu \mathrm{g} / \mathrm{ml}$ ascorbic acid, 10 $\mathrm{mM} \beta$-glycerophosphate and $100 \mathrm{nM}$ dexamethasone) were used as positive control. In the negative control group, cells were treated with DMEM alone. Cells were incubated at $37^{\circ} \mathrm{C}$ in humidified atmosphere of $95 \%$ air and $5 \% \mathrm{CO}_{2}$ with change of medium after every 3rd day. Photographs were taken on days 7, 14, 21 and 28. At day 28, after the nodule formed, the medium was removed. Cells were then washed with PBS twice. Cells were fixed with $100 \%$ cold methanol for 10 minutes and then rinsed twice with deionized water. Cells were stained with $1 \%$ Alizarin Red S (pH 4.1-4.3) (SigmaAldrich, USA) for 10 minutes, after removing dye, and rinsed with deionized water and air dried for 1 day. Next day photographs were taken of the nodules. The number of nodules were counted and calculated per area.

\subsection{Alkaline phosphatase activity assay}

On day 7, 14 and 21, cells were washed twice with PBS and lysed with lysis buffer (400 $\mu$ l) containing $1 \mathrm{mM}$ Phenylmethanesulfonyl fluoride (PMSF; SigmaAldrich, USA) and Cell Lytic M (Sigma-Aldrich, USA) for 15 minutes. Then cells were scraped and transferred to microtubes followed by centrifugation at $14,000 \mathrm{rpm}$ for 15 minutes at $4^{\circ} \mathrm{C}$. Then the supernatant was collected and stored at $-80^{\circ} \mathrm{C}$ until use. $100 \mu \mathrm{l}$ pNPP (pnitrophenyl phosphate) was added to $50 \mu 1$ sample and incubated at $37^{\circ} \mathrm{C}$ for $30 \mathrm{~min}$. Alkaline phosphatase enzyme activity was calculated from the absorbance of p-nitrophenol product formed at $405 \mathrm{~nm}$ determined using a microplate reader (Bio-Rad).

\subsection{Free radical scavenging assay}

Antioxidant activity of T.laeviceps propolis was measured based on the scavenging effect of propolis on 2,2-diphenyle-1-picryl-hydrazyl radical (DPPH) (St.Louis, USA). Ascorbic acid was used as the reference antioxidant ${ }^{12}$ (Yamaguchi et al., 1998). A solution containing various concentrations of propolis was used to assess their antioxidant activity. Absolute ethanol $(0.1 \mathrm{ml}$ of absolute ethanol and $3.9 \mathrm{ml}$ of $60 \mu \mathrm{M}$ DPPH solution) was used as the negative control and $60 \mu \mathrm{g} / \mathrm{ml}$ ascorbic acid was used as a positive control. All tubes were incubated at $28^{\circ} \mathrm{C}$ for 30 minutes, after which the absorbance was read at $515 \mathrm{~nm}$, against absolute ethanol as the blank. All experiments were performed in triplicate at each concentration. Percentage DPPH radical scavenging activity was calculated by the following equation:

$\% \mathrm{DPPH}$ radical scavenging activity $=\left\{\left(\mathrm{A}_{\mathrm{c}}-\right.\right.$ $\left.\left.\mathrm{A}_{\mathrm{s}}\right) / \mathrm{A}_{\mathrm{c}}\right\} \times 100$

where $A_{c}$ is the absorbance of the control, and $\mathrm{A}_{\mathrm{s}}$ is the absorbance of the test samples or standard. Then $\%$ of inhibition was plotted against concentration, and the $\mathrm{IC}_{50}$ was determined.

\section{RESULTS}

\subsection{Cell viability}

The results showed that propolis from $T$. Laeviceps up to $200 \mu \mathrm{g} / \mathrm{ml}$ produced no toxicity to PDL fibroblasts as shown in Figure 1. T. Laeviceps propolis at the concentrations of $0.1 \mu \mathrm{g} / \mathrm{ml}$ and $1 \mu \mathrm{g} / \mathrm{ml}$ could also promote PDLF proliferation as shown in Figure 2. It was also found that $10 \%$ DMSO was toxic and cell viability was reduced to only $28 \%$.

\subsection{In vitro wound healing assay}

The cell culture wound-closure and the trans well migration assays were performed to determine the migration of cell horizontally and vertically. The results showed that $T$. Laeviceps propolis at the concentrations of $0.1 \mu \mathrm{g} / \mathrm{ml}, 1 \mu \mathrm{g} / \mathrm{ml}$ and $10 \mu \mathrm{g} / \mathrm{ml}$ could significantly promote PDLF migration into scratched area as shown in Figure 3. The number of migrated cells were counted per area and showed in Figure 4. The greatest migration activity was found at the concentration of $10 \mu \mathrm{g} / \mathrm{ml}$. Statistical significant difference was found in the group of $0.1,1,10$ and $100 \mu \mathrm{g} / \mathrm{ml}$. In order to confirm the effect of propolis on PDLF migration the transwell cell migration assay was performed. The result showed similar effect to the scratch assay. T. Laeviceps propolis 


\section{Cell viability (\%)}

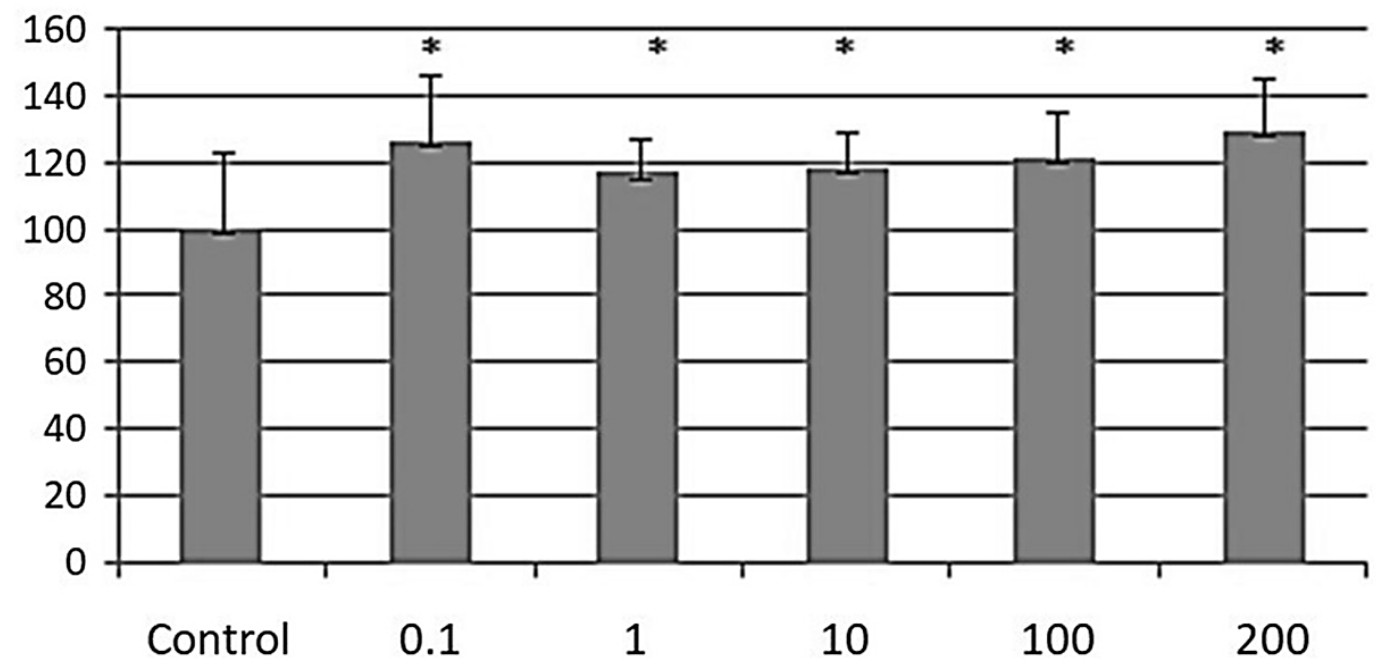

Concentration of propolis $(\mu \mathrm{g} / \mathrm{ml})$

Figure 1. Percentage of cell viability after treated PDLF with various concentration of $T$. laeviceps propolis. Each bar represents a mean with $\mathrm{SD}(\mathrm{n}=6)$. A significant differences shown as asterisk $(*)$ at $\mathrm{p}<.05$ when compare with control group.

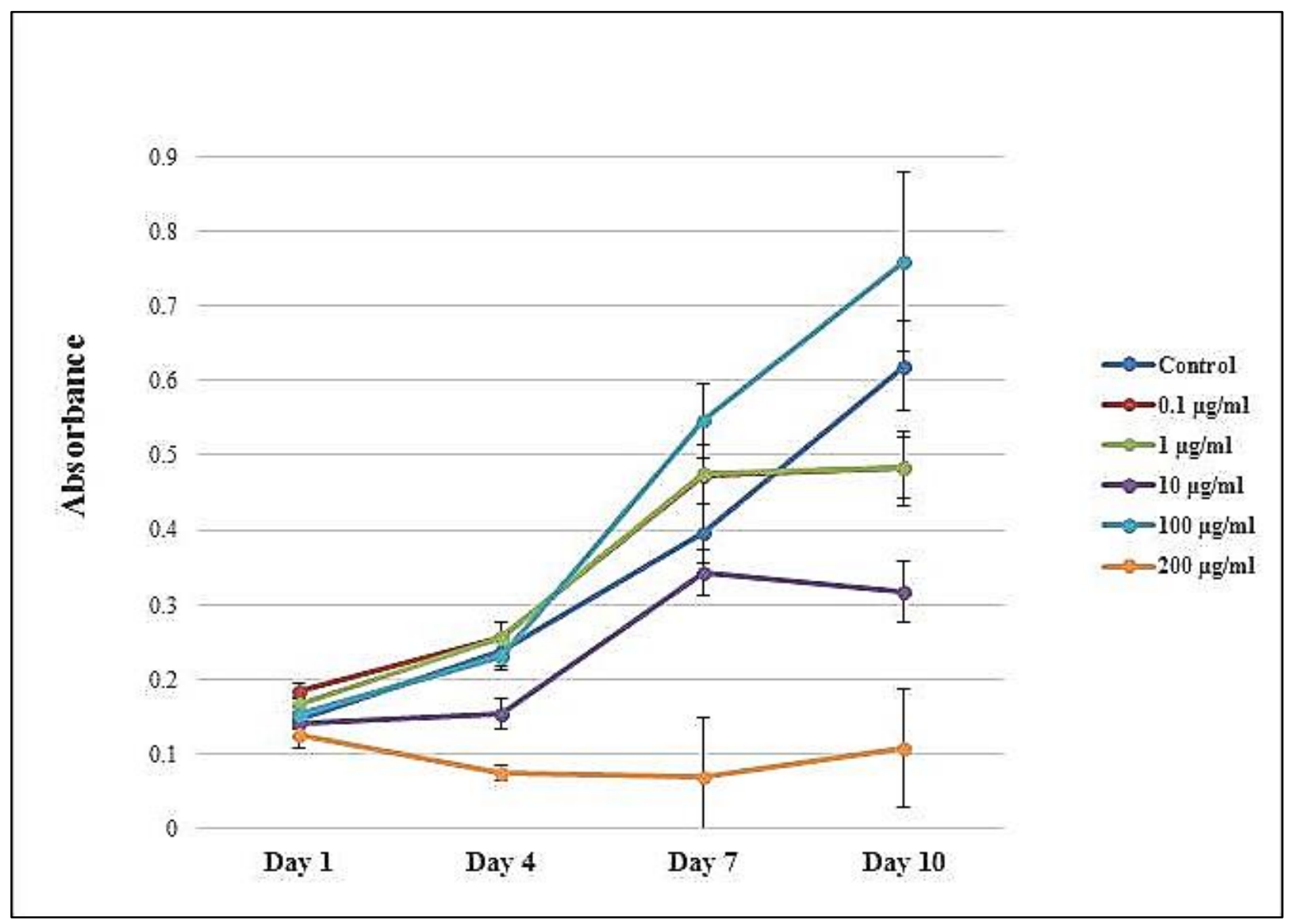

Figure 2. Effect of propolis on PDLF cell proliferation $(n=3)$. 

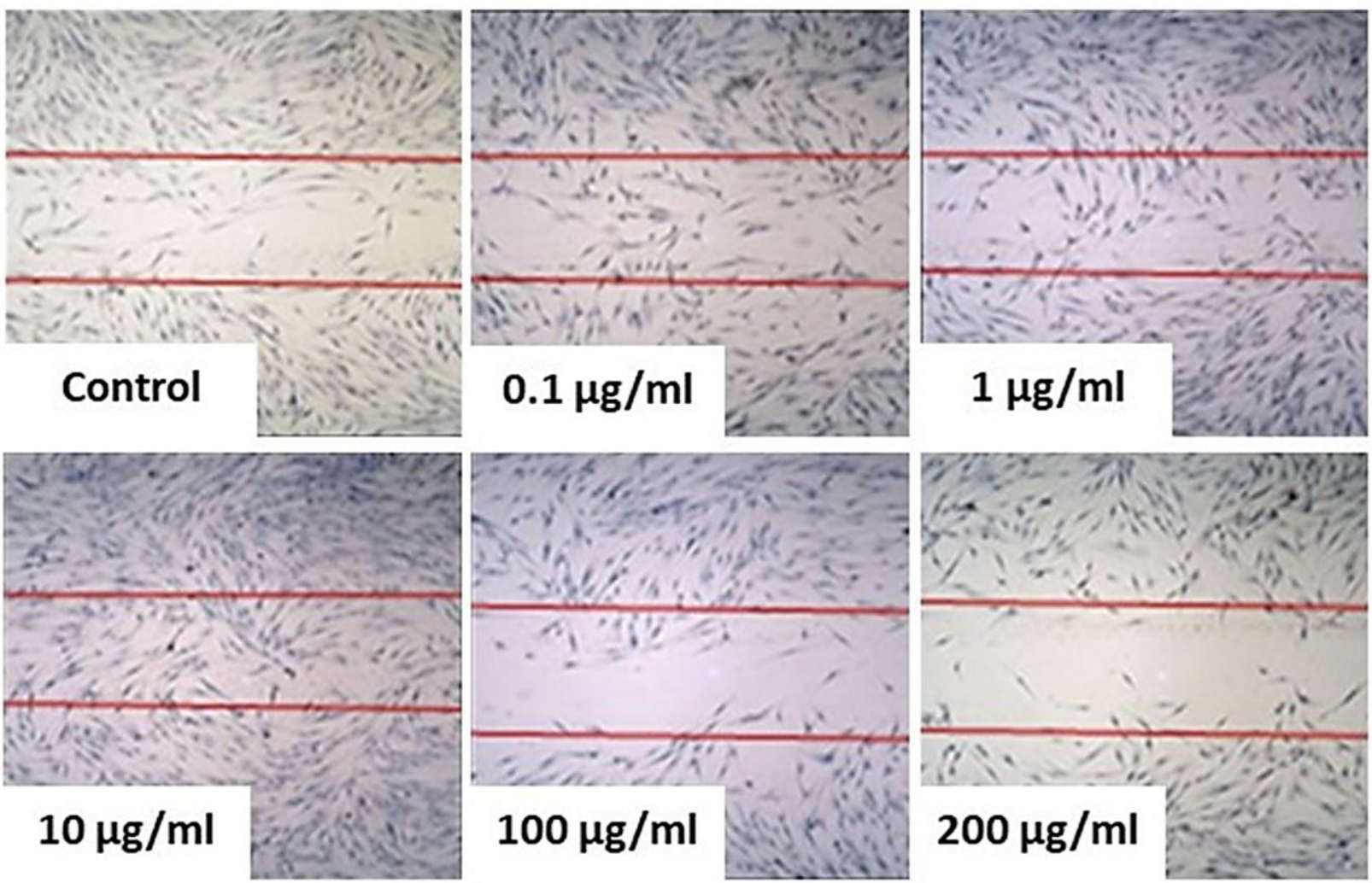

$10 \mu \mathrm{g} / \mathrm{ml}$

$100 \mu \mathrm{g} / \mathrm{ml}$

Figure 3. Horizontal migration assay of cell treated with propolis.

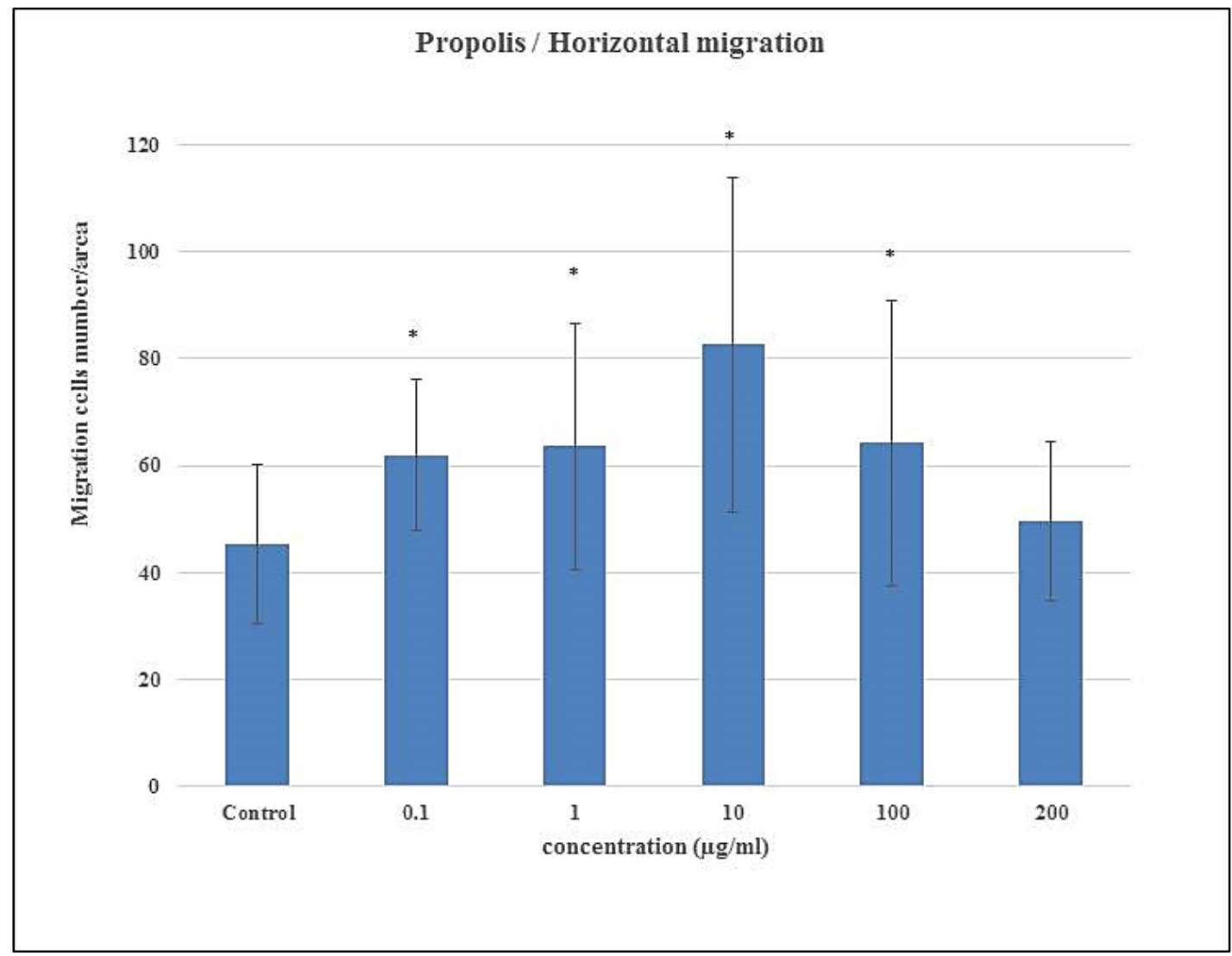

Figure 4. Number of cells migrated horizontally after treated with various concentrations of propolis. Each points and bar represents a mean with $\operatorname{SD}(n=3)$. A significant differences shown with asterisk $(*)$ at $p<.05$ when compare with the control group. 
could significantly promote vertical cell migration through the membrane at the concentrations of 0.1 and $1 \mu \mathrm{g} / \mathrm{ml}$ as shown in Figure 5.

\subsection{Alkaline phosphatase activity}

The level of alkaline phosphatase activity, shown in Figure 6, increased markedly in the propolis treated and inducer treated groups at day 14, but then decreased. Surprisingly, the level of alkaline phosphatase activity in propolis treated sample was lower in the presence of inducer compared to in the absence of inducer.

\subsection{Nodule formation}

At day 21, cells treated with propolis, propolis with inducer, and with inducer only showed a tendency to clump and form foci, while negative control group cells appeared normal but reached confluency. At day 28, mineralized nodules were observed and could be stained with Alizarin Red S, as shown in Figure 7. It was found that propolis could induce nodule formation without inducers.

Cells treated with propolis showed the highest numbers of nodule formation, which were nearly 2 folds higher than in the positive control group. Mineralized nodule was not formed in the negative control group without inducers (Table 1). Propolis appears to have no synergistic effect in inducing nodule formation, since the number of nodules found in the propolis plus inducer group was a little less than in the group with inducer alone. However, the size of mineralized nodules varied.

\subsection{Free radical scavenging effect}

The antioxidant activity of propolis was measured based on the scavenging effect of propolis on the stable free DPPH. The results showed that the antioxidant activity of propolis was dose dependent, with higher concentration showing greater antioxidation effect, as shown in Figure 8. The dose giving 50\% effect $\left(\mathrm{EC}_{50}\right)$ was $3.4 \mathrm{mg} / \mathrm{ml}$.

\section{DISCUSSION}

Effective treatment of periodontal diseases requires reducing inflammation and promoting both hard and soft tissue regeneration. In recent years, many researchers have been studying stem cell-mediated periodontal regeneration ${ }^{13}$ (Barosso et al., 2012).

PDLF, the most important cells in the periodontium, have been suggested to play an important role during periodontal wound healing leading to periodontal tissue regeneration ${ }^{14-15}$ (Iaska et al., 2001), (Wang et al., 2011). Periodontal ligament fibroblasts have been reported to possess stem cell properties, e.g. expression of stem cell markers ${ }^{16}$ (Nomura et al., 2012), the ability to differentiate and the ability to form mineralized nodules ${ }^{15}$ (Wang et al., 2011). This cell was therefore selected to use in this study.

Propolis is one of the few natural remedies that have maintained popularity over a long period of time. Previous studies showed many biological properties of propolis such as wound healing ${ }^{13}$ (Barroso et al., 2012), anti-inflammation ${ }^{17}$ (Dobrowolski et al., 1991), antioxidant activity ${ }^{18}$ (LeBlanc et al., 2012). However, different bees produce different propolis due to both species and living environment. This study is the first to study the effect of propolis obtained from Thai Tetragonula laeviceps (Thai stingless bee) on PDLF migration in vitro. Therefore, cytotoxicity tests need to be performed on this cell type, and the viability of PDLF cells after treatment with propolis for 24 hours was measured by the colorimetric MTT assay.

The results showed that cells treated with propolis showed significant difference in cell viability at concentration $200,100,10,1,0.1 \mu \mathrm{g} / \mathrm{ml}$, but no toxicity was found at all concentrations tested. The ethanolic extract of $T$. laeviceps propolis was previously reported to contain compounds with in vitro antiproliferative activity on 5 carcinoma cell lines (Chago, Kato-III, SW620, BT474 and HepG2). In the same paper, the propolis extract also showed cytotoxic activityity on two normal cell lines namely HS27 and CH-liver cells ${ }^{5}$ (Umthong et al., 2009), with IC50 values of $37.85 \mu \mathrm{g} / \mathrm{ml}$ and $29.14 \mu \mathrm{g} / \mathrm{ml}$, respectively. It was also reported that $100 \mu \mathrm{g} / \mathrm{ml}$ water extract and $100 \mu \mathrm{g} / \mathrm{ml}$ methanolic extract of $T$. laeviceps propolis had little antiproliferative effect on SW620 colon cancer cells, with more $80 \%$ cell viability remaining ${ }^{5}$ (Umthong et al., 2009). Interestingly, it was found that our study shows that T. laeviceps propolis up to $200 \mu \mathrm{g} / \mathrm{ml}$ showed no cytotoxic activity to PDLF. This may be due to a difference in the propolis extract used since the propolis in this study was crude extract dissolved in DMSO. Moreover, different type of cells may respond differently to toxic substances, PDLF have been suggested to tolerate propolis better than Hanks balanced salt solution ${ }^{19}$ (Gjertsen et al., 2011). It has been suggested that propolis solution can be used to preserved dental pulp and periodontal ligament fibroblasts which may have possible use as an alternative intercanal medication in endodontic treatment ${ }^{20}$.

Tests of cerumen from Brazilian stingless bees with the Artemia salina lethality assay showed some samples having surprisingly high cytotoxicity, whiles others appeared to be non-toxic ${ }^{21}$ (Velikova et al., 2000). Many other studies of A. mellifera propolis extract have shown different cytotoxic concentrations to different cell types in vitro ${ }^{22}$ (Teerasripreecha et al., 2012). The complex composition of propolis may 


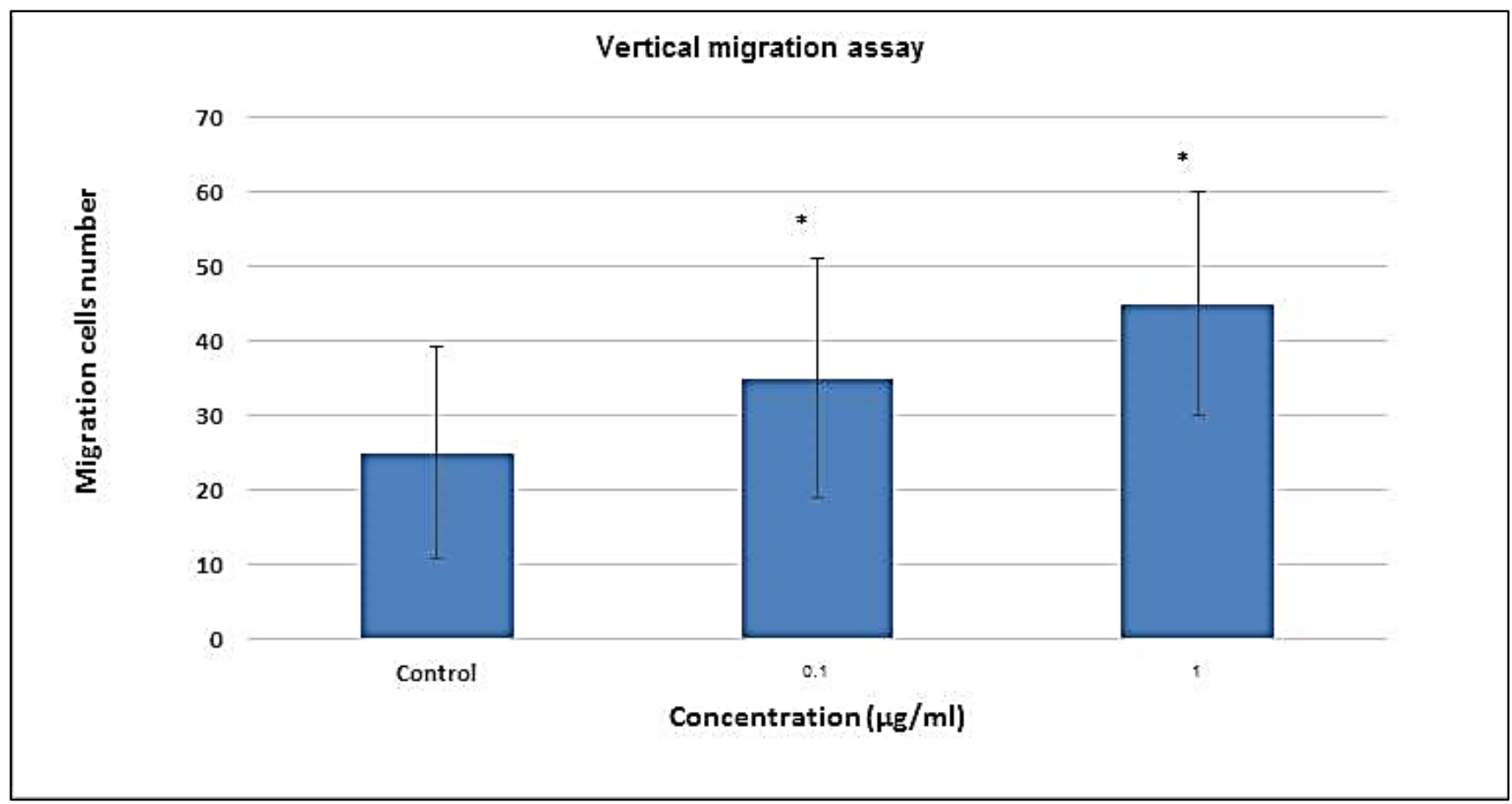

Figure 5. Number of cells migrated vertically after treated with various concentrations of propolis. Each points and bar represents a mean with $\mathrm{SD}(\mathrm{n}=3)$. A significant differences shown with asterisk $(*)$ at $\mathrm{p}<.05$ when compare with the control group.

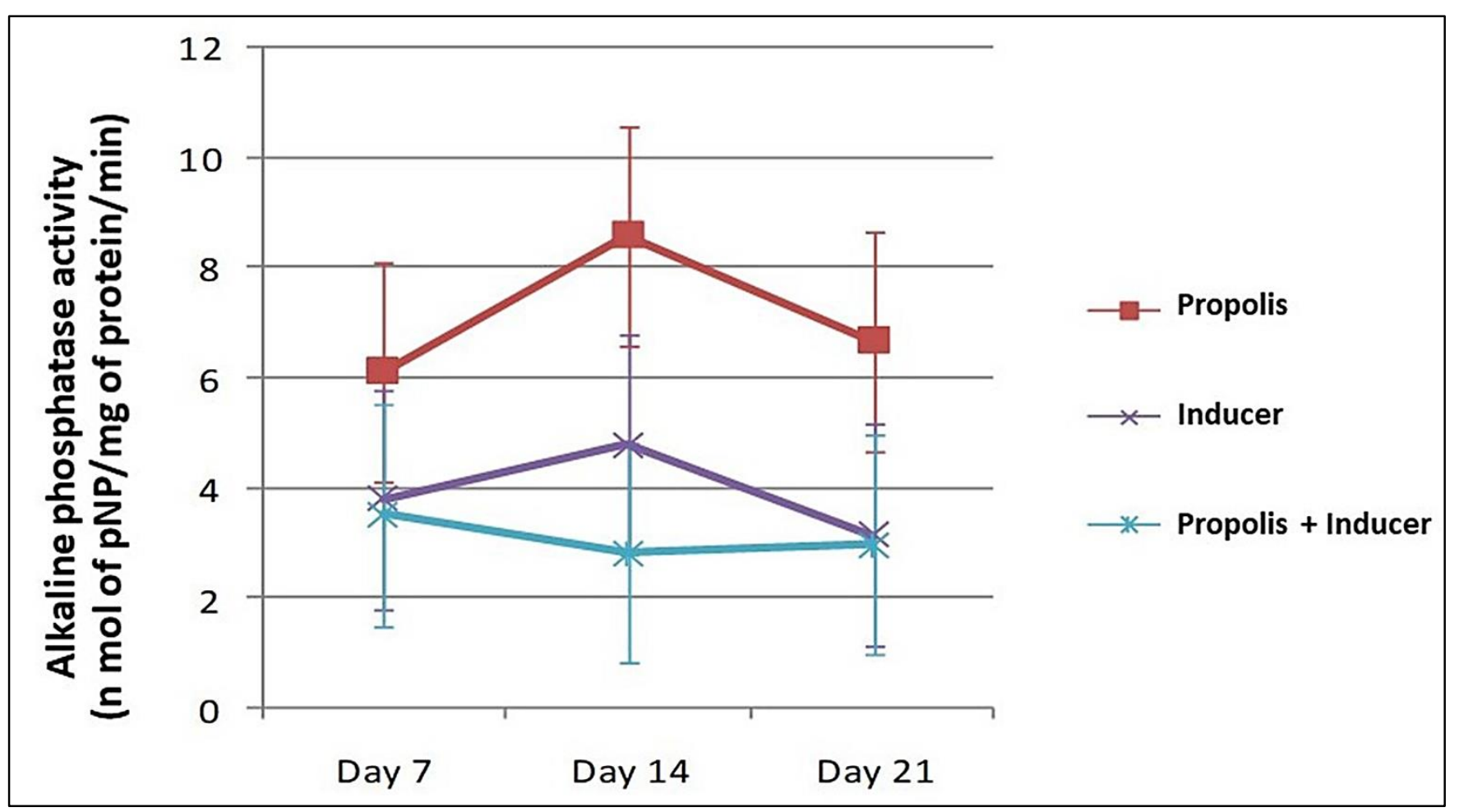

Figure 6. The alkaline phosphatase activity of PDLF cells expressed in nmol of $\mathrm{pNP} / \mathrm{mg}$ protein/min.

Table 1. Number of mineralized nodules formed calculated from a representative experiment.

\begin{tabular}{|c|c|}
\hline Condition & Number of Nodules per $\mathbf{c m}^{2}$ \\
\hline Propolis $10 \mu \mathrm{g} / \mathrm{ml}$ & 139.9 \\
\hline Propolis + Inducer & 51.3 \\
\hline Positive control & 70.8 \\
\hline Negative control & 0 \\
\hline
\end{tabular}




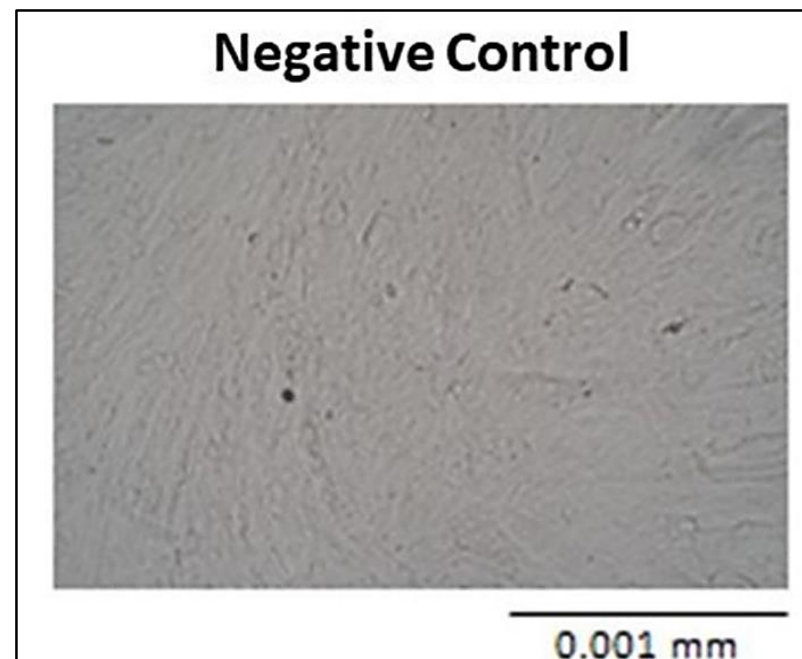

Positive Control

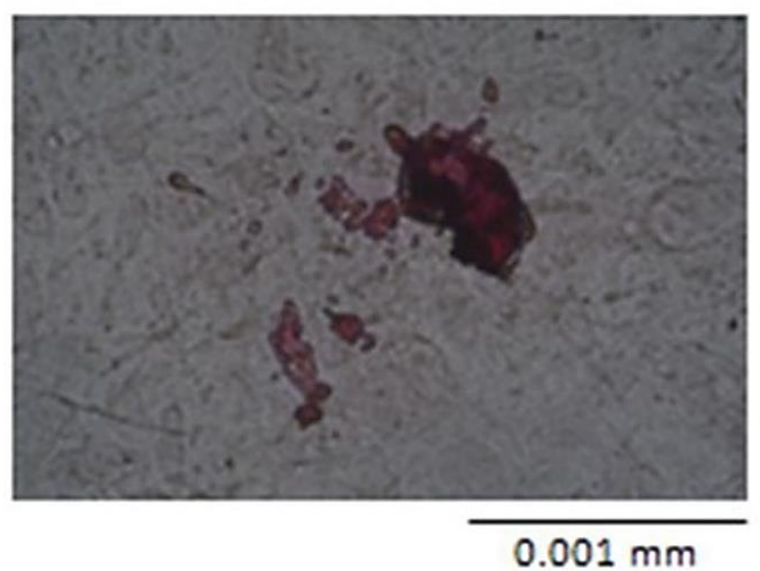

Propolis

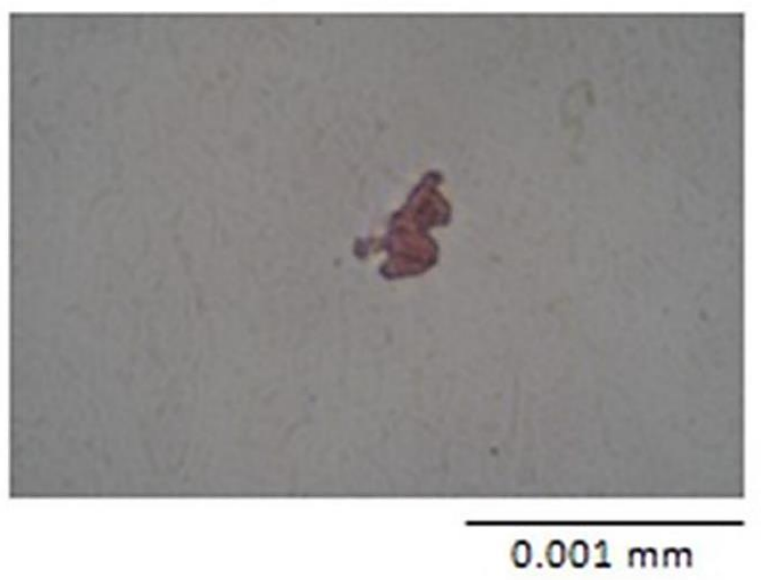

Propolis + Inducer

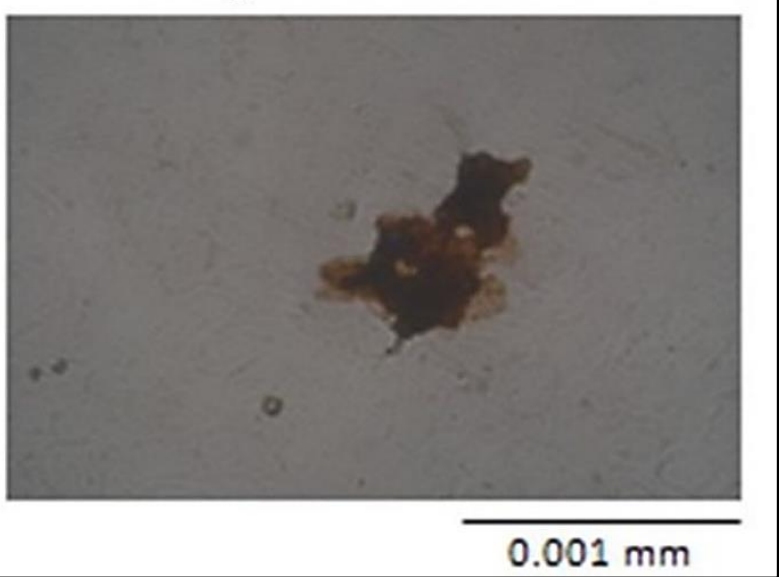

Figure 7. Representative photograph of mineralized nodule formation after staining with alizarin red S at day 28.



Figure 8. Antioxidant activity of T.laeviceps propolis at various concentrations. EC50 of propolis is $3.4 \mathrm{mg} / \mathrm{ml}$. 
explain why the propolis from the same type of bee could give apparently contradictory results, for example in anti-cancer activity and healing effect. The propolis collected in different seasons and at different places may also possess different properties too. This is the limitation of the study with crude extract.

The cell viability at those concentrations was confirmed by cell proliferation assay. Cells were grown in the presence and absence of propolis for 10 days. The results clearly showed that at the concentration of 100 $\mu \mathrm{g} / \mathrm{ml}$ of propolis, cells were still growing at similar rate to control, while at the concentration of $200 \mu \mathrm{g} / \mathrm{ml}$ cells were still viable. At the concentration of $200 \mu \mathrm{g} / \mathrm{ml}$, propolis could inhibit growth of PDLF and may begin to be slightly toxic. Therefore, the use of this crude propolis at higher concentrations than $200 \mu \mathrm{g} / \mathrm{ml}$ is not recommended. However, most interestingly, the cell proliferation assay showed that propolis at a concentration as low as $0.1 \mu \mathrm{g} / \mathrm{ml}$ could promote growth of PDLF.

The antioxidant activity of propolis was measured based on their scavenging effect on the stable free 2,2-diphenyl-1-picryl-hydrazyl radical.

The antioxidant activity of propolis samples from various countries, including Brazil, has been studied using this method. Red Brazilian propolis showed the best results ${ }^{23}$ (Trusheva et al., 2006). Another study of anti-oxidative property of propolis from 3 cities in the north of Brazil showed that the samples having higher phenolic and flavonoid contents showed higher anti-oxidant activity ${ }^{24}$ (Sawaya et al., 2011). In another study, the antioxidant activity was found to vary with different seasons ${ }^{25}$ (Simoes-Ambrosio et al., 2010).

In the present study, the results showed that the antioxidant activity of propolis is dose dependent, with higher concentrations giving higher antioxidant activity. The EC50 for propolis used in this study was $3.4 \mathrm{mg} / \mathrm{ml}$, indicating mild antioxidant activity. However, many reports showed that the antioxidant activities of many natural products vary greatly depending on source, season and collection process. With Chinese propolis, IC50 or ED50, varied between $21.79 \mu \mathrm{g} / \mathrm{ml}$ to 173.38 $\mu \mathrm{g} / \mathrm{ml}$ depending on the source of propolis.

Wound healing is a highly complex yet elegantly co-ordinated process. Like many biological phenomena, the study of wound healing has benefited from the use in vivo and in vitro models which have attempt to identify, isolate and simplify some of the processes associated with tissue repair ${ }^{26}$ (O'Leary et al., 2004). The aim of periodontal therapy is to regenerate and restore the periodontium ${ }^{27}$ (Garrett et al., 1996). Recent studies reported that regeneration of the destroyed periodontal attachment tissue is biologically possible ${ }^{28-}$ ${ }^{29}$ (Meyer et al., 1986, Gottlow. 1984). The goal of regeneration is to reconstitute the periodontal tissue onto a root surface that is the site of marginal periodontitis. In the periodontal regeneration process, progenitor periodontal ligament PDL cells need to migrate to the root surface, attach to it, proliferate and differentiate into an organized and functional fibrous attachment apparatus.

In this study we performed proliferation and migration assays both vertically and horizontally since this may be related to the migration process in periodontal diseases. First to confirm results using different assays and second; since in treatment of periodontal diseases sometimes need to perform surgical treatment and sometimes the guide tissue regeneration membrane may be needed. In order to regenerate bone in the periodontal diseases, the most important cells are periodontal ligament fibroblasts. These cells have to migrate to the defect bone area and also migrate vertically down under the gingiva. In treatment of severe periodontal diseases, surgical procedure may be required and guided tissue regeneration membrane may be needed. To start bone regeneration process the PDLF have to be able to migrate and proliferate into wounds area both horizontally and vertically, then they begin to deposit abundant ECM components during the final phase of wound healing. PDLF have been shown to be able to differentiate to become bone cell and help in mineralization process. Therefore both horizontal and vertical migration are important for the tissue regeneration process. The results showed that concentrations lower than $10 \mu \mathrm{g} / \mathrm{ml}$ of propolis for 24 hours could promote cell migration. On the other hand, propolis at the concentration of $1 \mu \mathrm{g} / \mathrm{ml}$ and $10 \mu \mathrm{g} / \mathrm{ml}$ could also promote PDL cell proliferation

In addition, the effect of propolis on the differentiation of human periodontal cell was studied. The results showed that all test groups and the positive control group could have formed mineralized nodules starting on day 24 and being clearly seen by staining on day 28 of culture, which correlated well with the ALP activity. There were the differences in the test groups and the positive control group, in terms of the number of mineralized nodules found. However, no mineralized nodule was detected in the negative control, which lacked inducers.

PDL cells consists of heterogeneous cells with osteoblastic, fibroblastic, or cementoblastic properties $^{30-31}$ (Yee et al., 1976, Pender et al., 1995). Previous studies have shown that PDLF cells can form bone-like mineralized nodules in the presence of ascorbic acid, $\beta$-glycerophosphate and dexamethasone in monolayer culture $^{32}$ (Cho et al., 1992). A similar study showed that Andrographis paniculata gel had the ability to induce differentiation of PDLF to osteoblast-like cells and formation of mineralized nodules at day 28 of culture ${ }^{33}$ (Sakulwan. 2008). Thus, in this study, the ALP activity and the mineralized nodule formation were used to investigate the direct effect of the propolis on a differentiation of human PDLF cells to osteoblast like cells 
in vitro. ALP is a calcium and phosphate binding protein and also an enzyme which hydrolyses monophosphate esters producing a high concentration of phosphates ${ }^{34}$ (Beertsen et al., 1989) leading to supersaturation and subsequent precipitation of calcium phosphate salt in the collagenous substrate ${ }^{35}$ (Martland et al., 1926). The activity of the enzyme is considered to be an important indicator of bone formation and a phenotypic marker of the osteoblastic cells. ALP appears to be an early marker of osteoblast differentiation and is expressed at high levels during the period of extracellular matrix deposition and then down-regulated after the mineralization stage $^{1}$ (Beck et al., 1998).

In the present study, the ALP activity continuously increased, and reaching its peak on day 14 in all groups, and then started to decrease. Cultured human periosteal-derived cells also showed increase in ALP expression for up to 2 weeks, with the continuous decrease thereafter ${ }^{36}$ (Perk et al., 2007). Therefore, our results showed a similar pattern of ALP activity in PDLF cells, but surprisingly, the level of ALP activity in PDLF also increased in the group lacking inducers. Moreover, the level of alkaline phosphatase activity in propolis treated sample was lower in the presence of inducer compared to in the absence of inducer. This may due to the antioxidant property of propolis which may react with ascorbic acid in the osteogenic medium and resulted in such response. The PDLF may possess a specific property, since PDLF contains stem cell property and can differentiate to other cell types such as osteoblast-like cells. The PDLF cells used in this study contain more than $99 \%$ stem cell property (data not shown). Thus, ALP activity increases during 14 days of culture, so the cells are ready to differentiate if the signal received. However, in the absence of inducer, cells will not differentiate and continue to grow as fibroblasts. Therefore, ALP activity may not be a good candidate for following the mineralization process in PDLF. However, it is interesting that propolis could induce ALP activity to increase and remain quite high after 14 day of culture. In addition, all test groups and the positive control group showed mineralized nodules starting on day 24 of culture, and the number and size of the nodules increase on day 28 of culture. However, differences in the number of mineralized nodules were found in the test groups and the positive control, but no mineralized nodule was detected in negative control group. Propolis alone could induce PDLF differentiation and mineralization, but use of propolis together with inducer actually caused reduction in the number of mineralized nodules, suggesting that these two substances may have some antagonistic effect on induction. The mineralized nodules may arise from osteoblast-like cells formed by PDLF differentiation or result from mineralization of PDLF itself. Further studies are needed clarify this, as well as to understand the mechanism of the induction.

The findings in this study clearly show that propolis from $T$. laeviceps could be used to induce bone formation. This is the first time that such property of this propolis has been described. The concentration used for induction is very low at the level of $0.1 \mu \mathrm{g} / \mathrm{ml}$ of propolis respectively, which is much lower than the EC50 found the free radical scavenging assay, so it is unlikely that these two properties are related.

The findings of the present study may help in the development of new drug to be used for treatment of periodontal disease, by which bone regeneration could be induced. With this property of this propolis, it will be interesting to see whether it may assist in other bone mineralization or bone tissue damage, such as in arthritis or other bone diseases. However, further clinical studies will be required to enable this natural product to be used in the effective manner.

Moreover, the study about other biological effect of propolis from $T$. laeviceps on other cell types may lead to the development of new regimen for treatment of other wound type.

\section{CONCLUSIONS}

Propolis from T. laeviceps can induce proliferation, migration and differentiation of PDLF. Thus, the results of this study could be used to support the use of these natural materials in dental practice for the treatment of periodontal diseases.

\section{ACKNOWLEDGEMENT}

This project is supported by Higher Education Commission and Mahidol University under the National Research Universities Initiative.

\section{Conflict of interest}

The authors declare no conflicts of interests.

\section{Funding}

None to declare.

\section{Ethics approval}

None to declare.

\section{Article info:}

Received June 8, 2020

Received in revised form November 12, 2020

Accepted December 9, 2020

\section{REFERENCES}

1. Beck JD, Eke P, Heiss G, Madianos P, Couper D, Lin D, et al. Periodontal disease and coronary heart disease: a reappraisal of the exposure. Circulation. 2005;112(1):19-24.

2. Lafon A, Pereira B, Dufour T, Rigouby V, Giroud M, Béjot Y, et al. Periodontal disease and stroke: a meta-analysis of cohort 
studies. Eur J Neurol. 2014;21(9):1155-61.

3. Sharma N, Shamsuddin H. Association between respiratory disease in hospitalized patients and periodontal disease: a crosssectional study. J Periodontol. 2011;82(8):1155-60.

4. Taheri JB, Azimi S, Rafieian N, Zanjani HA. Herbs in dentistry. Int Dent J. 2011;61(6):287-96.

5. Umthong S, Puthong S, Chanchao C. Trigona laeviceps propolis from Thailand: antimicrobial, antiproliferative and cytotoxic activities. Am J Chin Med. 2009;37(5):855-65.

6. Umthong S, Phuwapraisirisan P, Puthong S, Chanchao C. In vitro antiproliferative activity of partially purified Trigona laeviceps propolis from Thailand on human cancer cell lines. BMC Complement Altern Med. 2011;11:37.

7. Mosmann T. Rapid colorimetric assay for cellular growth and survival: application to proliferation and cytotoxicity assays. J Immunol Methods. 1983;65(1-2):55-63.

8. Jaiswal N, Haynesworth SE, Caplan AI, Bruder SP. Osteogenic differentiation of purified, culture-expanded human mesenchymal stem cells in vitro. J Cell Biochem. 1997;64(2):295-312.

9. Liang CC, Park AY, Guan JL. In vitro scratch assay: a convenient and inexpensive method for analysis of cell migration in vitro. Nat Protoc. 2007;2(2):329-33.

10. Chung CA, Chen CY. The effect of cell sedimentation on measuring chondrocyte population migration using a Boyden chamber. J Theor Biol. 2009;261(4):610-25.

11. Nohutcu RM, McCauley LK, Koh AJ, Somerman MJ. Expression of extracellular matrix proteins in human periodontal ligament cells during mineralization in vitro. J Periodontol. 1997;68(4):320-27.

12. Yamaguchi T, Takamura H, Matoba T, Terao J. HPLC method for evaluation of the free radical-scavenging activity of foods by using 1,1-diphenyl-2-picrylhydrazyl. Biosci Biotechnol Biochem. 1998;62(6):1201-4.

13. Barroso PR, Lopes-Rocha R, Pereira EM, Marinho SA, de Miranda JL, Lima NL, et al. Effect of propolis on mast cells in wound healing. Inflammopharmacology. 2012;20(5):289-94.

14. Isaka J, Ohazama A, Kobayashi M, Nagashima C, Takiguchi T, Kawasaki H, et al. Participation of periodontal ligament cells with regeneration of alveolar bone. J Periodontol. 2001;72(3): 314-23.

15. Wang L, Shen H, Zheng W, Tang L, Yang Z, Gao Y, et al. Characterization of stem cells from alveolar periodontal ligament. Tissue Eng Part A. 2011;17(7-8):1015-26.

16. Nomura Y, Ishikawa M, Yashiro Y, Sanggarnjanavanich S, Yamaguchi T, Arai $\mathrm{C}$, et al. Human periodontal ligament fibroblasts are the optimal cell source for induced pluripotent stem cells. Histochem Cell Biol. 2012;137(6):719-32.

17. Dobrowolski JW, Vohora SB, Sharma K, Shah SA, Naqvi SA, Dandiya PC. Antibacterial, antifungal, antiamoebic, antiinflammatory and antipyretic studies on propolis bee products. $\mathbf{J}$ Ethnopharmacol. 1991;35(1):77-82.

18. LeBlanc L, Paré A, Jean-François J, Hébert M, Surette M, Touaibia M. Synthesis and Antiradical/Antioxidant Activities of Caffeic Acid Phenethyl Ester and Its Related Propionic, Acetic, and Benzoic Acid Analoguesc. Molecules. 2012;17(12): 14637-50.

19. Gjertsen AW, Stothz KA, Neiva KG, Pileggi R. Effect of propolis on proliferation and apoptosis of periodontal ligament fibroblasts. Oral Surg Oral Med Oral Pathol Oral Radiol Endod. 2011;112(6):843-8.

20. Al-Shaher A, Wallace J, Agarwal S, Bretz W, Baugh D. Effect of propolis on human fibroblasts from the pulp and periodontal ligament. J Endod. 2004;30(5):359-61.

21. Velikova M, Bankova V, Marcucci MC, Tsvetkova I, Kujumgiev A. Chemical composition and biological activity of propolis from Brazilian meliponinae. Z Naturforsch C J Biosci. 2000;559-10):785-9.

22. Teerasripreecha D, Phuwapraisirisan P, Puthong S, Kimura K, Okuyama M, Mori $\mathrm{H}$, et al. In vitro antiproliferative/cytotoxic activity on cancer cell lines of a cardanol and a cardol enriched from Thai Apis mellifera propolis. BMC Complement Altern Med. 2012;12:27.

23. Trusheva B, Popova M, Bankova V, Simova S, Marcucci MC, Miorin PL, et al. Bioactive constituents of brazilian red propolis. Evid Based Complement Alternat Med. 2006;3(2):249-54.

24. Sawaya AC, Barbosa da Silva Cunha I, Marcucci MC. Analytical methods applied to diverse types of Brazilian propolis. Chem Cent J. 2011;5(1):27.

25. Simoes-Ambrosio LM, Gregorio LE, Sousa JP, FigueiredoRinhel AS, Azzolini AE, Bastos JK, et al. The role of seasonality on the inhibitory effect of Brazilian green propolis on the oxidative metabolism of neutrophils. Fitoterapia. 2010;81(8): $1102-8$.

26. O'Leary R, Rerek M, Wood EJ. Fucoidan modulates the effect of transforming growth factor (TGF)-beta1 on fibroblast proliferation and wound repopulation in in vitro models of dermal wound repair. Biol Pharm Bull. 2004;27(2):266-70.

27. Garrett S. Periodontal regeneration around natural teeth. Ann Periodontol. 1996;1(1):621-66.

28. Meyer JR. The regenerative potential of the periodontal ligament. J Prosthet Dent. 1986;55(2):260-5.

29. Gottlow J, Nyman S, Karring T, Lindhe J. New attachment formation as the result of controlled tissue regeneration. J Clin Periodontol. 1984;11(8):494-503.

30. Yee JA, Kimmel DB, Jee WS. Periodontal ligament cell kinetics following orthodontic tooth movement. Cell Tissue Kinet. 1976;9(3):293-302.

31. Pender N, Heaney TG. Migration and proliferation of progenitor cells in the connective tissue of rat gingival papilla. J Periodontal Res. 1995;30(5):312-8.

32. Cho M-I, Matsuda N, Lin W-L, Moshier A, Ramakrishnan PR. In vitro formation of mineralized nodules by periodontal ligament cells from the rat. Calcif Tissue Int. 1992;50(5):459-67.

33. Noppamassiri S, Sirirat M, Surarit R, Kasetsuwan J, Rojanapanthu P. The cytotoxic effect of Andrographis paniculata extract and Andrographis paniculata gel on human periodontal ligament cells. Mahidol Dent J. 2009;29(1):37-44.

34. Beertsen W, van den Bos T. Calcification of dentinal collagen by cultured rabbit periosteum: the role of alkaline phosphatase. Matrix. 1989;9(2):159-71.

35. Martland M, Robison R. Possible Significance of Hexosephosphoric Esters in Ossification: Part VI. Phosphoric Esters in Blood-Plasma. Biochem J. 1926;20(4):847-55.

36. Park BW, Hah YS, Kim DR, Kim JR, Byun JH. Osteogenic phenotypes and mineralization of cultured human periostealderived cells. Arch Oral Biol. 2007;52(10):983-9. 